\title{
The Coherence of Cognition and Identity of Villagers to Village Cadres: Case on the 334 Households in 15 Guangdong Villages
}

\author{
Qinjie Zhang \\ Department of Sociology, College of Public Management, South China Agricultural University, Guangzhou, China \\ Email: lindalion@msn.com
}

How to cite this paper: Zhang, Q. J. (2019). The Coherence of Cognition and Identity of Villagers to Village Cadres: Case on the 334 Households in 15 Guangdong Villages. Advances in Applied Sociology, 9, 370-378.

https://doi.org/10.4236/aasoci.2019.98027

Received: July 11, 2019

Accepted: August 18, 2019

Published: August 21, 2019

Copyright $\odot 2019$ by author(s) and Scientific Research Publishing Inc. This work is licensed under the Creative Commons Attribution International License (CC BY 4.0).

http://creativecommons.org/licenses/by/4.0/

\begin{abstract}
About the case on the 334 households of 15 villages in Guangdong Province, the study aimed to discuss the coherence of villagers' cognition and identity of the characteristics of village cadres. The study found that the core village cadres in the survey villages had the characteristics of male dominance, big surname dominant, relatively high educational level, and more than two consecutive terms. The villagers realized the village cadres were the person with great ability, and identity the person with great ability should be their cadres. There was a high coherence between villagers' cognition and identity of village cadre types. The social fact of "governing villages by able people" will be strengthening and universalization by a series of systems.
\end{abstract}

\section{Keywords}

Village Cadres, Villagers, Coherence, Chinese Village

\section{Introduction}

Who will govern Chinese villages? Under the leadership of the Village Party Organizations, based on the villagers autonomy, the view of the joint participation and joint governance was clear in the institution as "Opinions on Strengthening and Perfecting Community Governance in Urban and Rural Areas" (2017-6-12). As a self-governing organization for villagers' self-management, education and service, Villagers' Committees were under the leadership of basic-level Party Organizations in exercising their functions and powers based on the "Organic Law of the Villagers Committees of the People's Republic of China" (2018-12-29). "Some Opinions on Adhering to Priority Development of Agriculture and Rural Areas and Doing Well the Work of 'Three Rural Issues'” (2019-1-3) emphasized 
the importance to fully implement that the Secretary of the Village Party Organization should act as the Director of the Village Committee through legal procedures, and practice that the members of the "Two Committees" should serve in cross appointment.

When the leading and being led relationship among the multi-governance was established, they would avoid the dilemma of the structural matching among the multi-subject operation mechanism (Li, 2017) and the dilemma of the same practical situation (Li, 2007). The issue of "person" namely "village cadres" naturally became specially critical: whether we knew the process of village cadres or not; we knew who could become the village cadre; who was the village cadre and who should be the village cadre. These questions involved three different types of village cadres, namely, policy advocacy, actual governance and villagers' expectations.

\section{Literature Review about Village Cadres in China}

Studies on the Chinese village cadres mainly focused on the election and rural power distribution (Burns, 1978; O’Brien, 1994; Xiao, 2001; Tong \& He, 2002; Tong, 2016), personal characteristics and role behaviors (Wang, 1991; Wu, 2002; Sun, 2009; Hu, 2018), management and training mechanism (Ma \& Wang, 2017). These references were helpful to understand "who could be the village cadre" and "who was the village cadre".

Since the concept of "governing villages by able people" put forward ( $\mathrm{Lu}$, 1998), Xiang, H., \& Zhou, W.F. (2001) discovered the common phenomenon of economic-able people as village officials, He X.F. (2003) found the good, evil, strong and able four types of village cadres from the personal character and ability, Ye, B.Q. (2005) noticed the village tyrants, Xiao T.B. (2006) found that the combination of pre-endowed factors and self-induced factors of village cadres, Zhang, Y.E. (2010) divided the rural governance subjects into institutional and non-institutional subjects at the macro-institution level, as well as village cadres, elites and ordinary villages at the micro-behavioral level, Zhang J. (2011) discussed the political criteria for cadres recruitment. Gui, H. (2019) thought it was necessary to take the advantage of "Middle peasants governing villages".

But they didn't pay enough attention to the villagers, actually, the villagers always were the main component of Chinese villages and the direct beneficiaries of rural construction and governance. And if there were, they mainly focused on the opposition or conflict not the coherence between village cadres and villagers, and paid too little attention to what attitude the villagers held towards the village cadres and what kind of village cadres they expected. In short, they didn't answer "who should be the village cadre" and couldn't grasp the coherence among institutional opportunities, practice and villagers' expectations.

\section{Research Method}

Accordingly, based on the standpoint of villagers and non-conflict, this study 
explored the characteristics of the current village cadres, the villagers' cognition of the characteristics of the current village cadres, the villagers' identity the people with the characteristics as village cadres, and further compared the coherence between cognition and identity of, in order to finally find the coherence among institutional opportunities, practice and villagers' expectations.

The concept of coherence meant that there were match, correspondence and complementary among aspects in a certain category (Alkan, 2002). This concept summarized the match among the actual characteristics of village cadres, villagers' cognition and perception of village cadres in Chinese villages.

This study from the perspective of coherence was only a preliminary exploration on the coherence issue by using case studies. 15 administrative villages in Guandong were selected by non-random sampling method, because there were two different types of village, the economically developed Pearl River Delta and the economically backward non-Pearl River Delta. Opportunity sampling was used to conduct an effective household survey of Village Party Organizations, Village Committees and 334 rural households of 15 villages in Guangdong. Only one adult member of each household was surveyed. The data in the following five tables were all from this investigation.

Based on the references on the village cadre's role characteristics and researches on ability (Spearman, 1999 [China]; Wu \& Du, 2006), the survey contents of self-designed included 1) the demographic characteristics of the current and former of the Secretary of Village Party organizations and Village Committee Directors, such as gender, age, education and surname. 2) Villagers judged whether the core villages cadres were the strong economic ability, strong comprehensive coordination ability, good family economic conditions, strong family power, good relationship between county and town people and high morality in villages. 3) Villagers identified these people with same characteristics as village cadres and so on. 4) The information about villagers was measured by 5-point Likert Scale.

Because the villagers were individuals and the rural villagers were groups, in order to avoid the incoherence of the analysis object level, this study obtains the values of the rural villagers according to the aggregated average value.

\section{Analysis Results}

\subsection{The Population Structure Characteristics of Village Cadres}

In the surveyed villages, the average female population was 1347, more than the male; the people over 18 years old who had the right to vote were over two-thirds of the average village population.

\subsubsection{Common Re-Election, Male Dominated and Surname Dominated} From the number of appointments, it was general phenomenon that most of the Secretary of village Party organizations and Village Committee Directors had been re-elected more than twice, such as $78.6 \%$ of the current Secretary of Vil- 
lage Party Organizations, $83.3 \%$ of the former; $60 \%$ of the current Village Committee Directors and $64.3 \%$ of the former. Among these, there were $14.3 \%$, $16.7 \%, 13.3 \%$ and $7.1 \%$ who had been re-elected more than five times.

From the perspective of gender collocation, most of them are male, and even some villages had no female cadres at all. Table 1 reflected the situation that the Village Committee Directors and the Secretary of Village Party Organizations in the investigation villages were dominated by surnames, both former and current. Even $40 \%$ of the village's current and former village cadres were the first surname clan of the village; $70 \%$ were the first or second surname clan, and the proportion of the minority surname persons as village leaders was not more than $30 \%$.

\subsubsection{Age Older and Relatively Higher Level of Education}

Table 2 showed that the current director of the village committee had a higher educational level than his predecessor, and the Secretary of the village party organization had a higher educational level than the director of the village committee. The age of the director of the village committee was younger than that of the Secretary of the village party organization. Specifically, the current average age, village committee directors was 44.53 years old, which is smaller than 52.14 years old of the Secretary of the village party organization; 30 - 39 years old, village committee directors account for 26.7\%, 19.6\% more than the Secretary of the village party organization; 40 - 49 years old, the village committee directors account for $46.7 \%$, the Secretary of the village party organization account for 21.6\%; 50 years old and above, village committee directors account for $26.6 \%$, the Secretary of the village party organization account for $71.3 \%$. The average age of leaving office, it was 52.09 years old for the former director of the village committee and 55.73 for the former the Secretary of the village party organization. In terms of educational level, the currents had a higher educational level than their predecessors, there were $63.5 \%$ of the current directors and $53.3 \%$ of the former directors, $66.7 \%$ of the current Secretary and $53.8 \%$ of the former, who had a high school or above level.

\subsection{Types of Village Cadres in the Eyes of Villagers}

\subsubsection{Villagers' Cognition of Village Cadres: Able People Governing Villages}

By measuring the index of whether the current village cadres were the strong comprehensive coordination ability, high morality in villages, good relationship between county and town people, higher education, older people, good family economic conditions and strong family force (yes $=1$, no $=0$ ), it found that most villagers recognized that their village cadres were strong coordinators, well-connected people in counties and towns, family economic rules and high-esteem in village, the proportion was respectively $73.3 \%, 73.3 \%, 66.7 \%$ and $66.7 \%$, the lowest proportion was $33.3 \%$ for those cadres with higher education level. 
Table 1. Name characteristics of the current and former core village cadres $(\mathrm{N}=15)$.

\begin{tabular}{ccccc}
\hline Core cadres & First surname & Second surname & Third surname & Less surname \\
\hline Current director & 53.33 & 20.00 & 0.00 & 26.67 \\
Former director & 66.67 & 13.33 & 0.00 & 20.00 \\
Current secretary & 64.27 & 7.14 & 7.14 & 21.43 \\
Former secretary & 57.14 & 7.14 & 7.14 & 28.57 \\
\hline
\end{tabular}

Table 2. Population structure characteristics of current and former village cadres $(\mathrm{N}=$ 15).

\begin{tabular}{ccccc}
\hline Index & Min & Max & Mean & SD \\
\hline Age of the current director & 30 & 60 & 44.53 & 8.79 \\
Educational level of the current director & 2 & 4 & 3.56 & 0.62 \\
Educational level of the former director & 1 & 5 & 3.40 & 1.04 \\
leaving of the former director & 35 & 65 & 52.09 & 10.15 \\
Age of the current Secretary & 33 & 62 & 52.14 & 7.77 \\
Educational level of the current Secretary & 2 & 9 & 4.20 & 1.71 \\
Educational level of the former Secretary & 2 & 9 & 3.85 & 1.64 \\
Leaving Age of the former Secretary & 43 & 65 & 55.73 & 7.71 \\
\hline
\end{tabular}

In order to better discover the villagers' cognition of the characteristics of village cadres, the study made an effort to do the exploratory factor analysis and got the 0.663 of KMO value, was close to 0.7 , Bartlett's test $\chi^{2}$ was 60.4 , the significance was 0.000 . These meant that the exploratory factor analysis could be done. In Table 3, the total variance explained of two component factors to seven indicators was $77.245 \%$. The component score coefficient was relatively centralized. Because the component factors 1 and 2 reflected the self-achieved factors and ascriptive factors so they were named as "capability-based cadres" and "resource-based cadres" respectively, instead of the original seven indicators. The analysis showed that $73.3 \%$ of the villagers thought their cadres are capability-based cadres, which meant that most villagers recognize the reality of governed villages by able people.

\subsubsection{Villagers' Expectation of Village Cadres: Majority Preference for Able People}

Rural villagers' cognition of the Cadres based on the presentational features of village cadres, which was not equal to their expectations or identities of the Cadres. Therefore, the study continues to explore what type of villagers' expectations for their cadres. Though the identity of the seven features mentioned above was measured by the 5-point Likert scale, the survey found that the villagers identified their cadres with strong comprehensive coordination ability, the high-esteemed in the village and the high education level, the proportion in turn was $93.3 \%, 86.7 \%$ and $80.0 \%$, but there was lower proportion of those who identified with the strong clan, the older, and the better family economic conditions, the proportion one by one was $13.3 \%, 20.0 \%$ and $26.7 \%$. 
Table 3. Component score coefficient matrix of cognition of cadres types.

\begin{tabular}{ccc}
\hline Index & 1 & 2 \\
\hline Cadres with comprehensive Coordination ability & 0.885 & -0.232 \\
Cadres with high-esteemed in village & 0.865 & -0.175 \\
Cadres with good relation of country town people & 0.839 & 0.352 \\
Cadres with high education level & 0.747 & -0.460 \\
Cadres were older people & 0.733 & -0.239 \\
Cadres with better family economical condition & -0.015 & 0.873 \\
Cadres with strong clan & -0.298 & 0.866 \\
\hline
\end{tabular}

Extraction Method: Principal Component Analysis; Rotation Method: Varimax with Kaiser Normalization; a. Rotation converged in 3 iterations.

In order to compare with the villagers' cognitive types of village cadres, the study used exploratory factor analysis again, and found that $\mathrm{t}$ KMO value was 0.659 , close to 0.7 , Bartlett's test $\chi^{2}$ was 65.466 , and the significance was 0.000 , which indicated that the exploratory factor analysis could be done. In Table 4, the total variance explained of two component factors to seven indicators was $73.783 \%$, the component score coefficient was relatively centralized, the study got two Component factors same as Table 3, named as "capability-based cadres" and "resource-based cadres". $73.3 \%$ of villagers identified their cadres as capability-based cadres, which indicated that most villagers expected the capability-based cadres.

\subsection{The High Coherence of Villagers' Cognition and Identity of Cadres}

Table 5 showed the correspondence and coherence of the types of village cadres perceived and identified by villagers. $66.7 \%$ of the villagers have the same recognition and identity of the type of village cadres, which meant that the village cadres' type had integrated of the village reality, villagers' cognition and villagers' identity. There were $53.3 \%$ of capability-based cadres, $13.3 \%$ of resource-based cadres, $13.3 \%$ belonging to resource-based cadres but expectations of capability-based cadres, $20.0 \%$ belonging to capability-based cadres but expectations of resource-based cadres.

\section{Discussion}

Through the survey analysis of 15 villages in Guangdong Province, the study found the fact that 1) The village cadres were mainly male-dominated, first surname with clan, relatively high educational level, re-election, and older people. 2) There were two types of village cadres in villager's eye, capability-based cadres and resource-based cadres. 3) Most villagers perceived that the village was governed by capability-based cadres. 4) Most villagers identified the capability-based person as their village cadres. 5) There was a relatively high coherence between villagers' cognition and identity of the type of cadres. 
Table 4. Component score coefficient matrix of identity of cadres types.

\begin{tabular}{ccc}
\hline Index & 1 & 2 \\
\hline Identity degree with high-esteemed in village & 0.927 & 0.015 \\
Identity degree with comprehensive Coordination ability & 0.907 & -0.216 \\
Identity degree with older people & 0.788 & -0.128 \\
Identity degree with strong clan & -0.676 & 0.528 \\
Identity degree with high education level & 0.593 & -0.458 \\
Identity degree with good relation of country town people & 0.073 & 0.846 \\
Identity degree with better family economical condition & -0.424 & 0.776 \\
\hline
\end{tabular}

Extraction Method: Principal Component Analysis; Rotation Method: Varimax with Kaiser Normalization; a. Rotation converged in 3 iterations.

Table 5. The coherence between cognition and identity of cadres type by villagers.

\begin{tabular}{|c|c|c|c|c|c|}
\hline Regional & Municipa & Village & Cognition & Identity & Coherence \\
\hline \multirow{6}{*}{$\begin{array}{l}\text { Non-Pearl } \\
\text { River Delta }\end{array}$} & \multirow{2}{*}{ Zhanjiang } & Xiwan & Capability & Resource & no \\
\hline & & Shuiyuan & Resource & Resource & yes \\
\hline & \multirow[t]{2}{*}{ Yunfu } & Pingkang & Capability & Capability & yes \\
\hline & & Fengkou & Capability & Capability & yes \\
\hline & \multirow[t]{2}{*}{ Meizhou } & Fuling & Capability & Capability & yes \\
\hline & & Qidu & Capability & Capability & yes \\
\hline \multirow{9}{*}{$\begin{array}{l}\text { Pearl River } \\
\text { Delta }\end{array}$} & Jiangmen & Shishun & Capability & Capability & yes \\
\hline & \multirow{5}{*}{ Huizhou } & Jiutan & Capability & Resource & no \\
\hline & & Hongwei & Capability & Capability & yes \\
\hline & & Baisha & Capability & Capability & yes \\
\hline & & Yihe & Resource & Capability & no \\
\hline & & Shenli & Resource & Capability & no \\
\hline & \multirow{3}{*}{ Guangzhou } & Changgeng & Capability & Capability & yes \\
\hline & & Nangang & Capability & Resource & no \\
\hline & & He Tang & Resource & Resource & yes \\
\hline
\end{tabular}

Able people were governing surveyed villages and able people should govern surveyed villages, this meant it has a truly social foundation. The find affirmed the view that "governing villages by able people" would be the direction of modernization of grassroot governance (He, 2018). Early stage, "governing villages by able people" meant one or few able people dominated the operation of public power with low institutionalization ( $\mathrm{Lu}, 1998)$. But now, the social fact of "governing villages by able people" would be strengthening and universalization by "Regulations of the Communist Party of China on the work of Rural Grass-roots Organizations" (2019-1-10). This institution clearly advocated that the reserve force at village level should be from the villager party member with rich skills, from the returnees of work and business, from the university graduates from lo- 
cal village, from the veterans. In principle, the Party Members' Congresses should elect them, but if the work needed, the higher Party Organizations could choose them.

Excessive "elitism" (Zhang \& Ren, 2008) and "oligarchy" (Chen, 2016) "fragmentation" (Yang, $\mathrm{Xu}, \& \mathrm{Xu}, 2015)$ might arise from the practical process of "governing villages by able people". Under the convoy of CPC in charge everything and catching the key minority, the effect of "governing villages by able people" still needed to be tested in China's Rural Revitalization Plan.

\section{Conclusion}

From the relatively high coherence of villagers' cognition and identity of the type of cadres, surveyed village cadre had the foundation of villagers. Four aspects like Policy support and factual characteristics of village cadres, and villagers' perception and villagers' identit consolidated the legitimacy foundation of villages governed by able-based people from advocacy, facts, cognition and wish. "Governing villages by able people" was existing and would become the main type of Chinese grassroot governance.

\section{Conflicts of Interest}

The author declares no conflicts of interest regarding the publication of this paper.

\section{References}

Alkan, A. (2002). A Class of Multipartner Matching Markets with a Strong Lattice Structure. Economic Theory, 4, 737-746. https://doi.org/10.1007/s001990100179

Burns, J. P. (1978). The Election of Production Team Cadres in Rural China: 1958-74. The China Quarterly, 74, 273-296. https://doi.org/10.1017/S0305741000042272

Chen, P. (2016). Urban Community Governance: Basic Models and Governance Performance: A Case Study of Four Commodity Housing Communities. Sociological Studies, 3, 125-151.

Gui, H. (2019). Who Will Govern the Villages: Training and Selection of Village Cadres in the New era. People's Forum, 11, 96-98.

He, X. F. (2003). The Social Foundation of Rural Governance: A Study on the Nature of Rural Society in the Transitional Period. Beijing: China Social Science Press.

He, X. F. (2018). Governing Villages by Able People and the Modern Direction of Grassroots Governance: Starting from the Investigation of Wangting Town in Suzhou. Changbai Journal, 3, 57-61+2.

Hu, Y. F. (2018). Diachronic Evolution of "Name" and "Reality" of Village Cadres: Based on the Field Survey in Zhejiang Zhaocun. Journal of Huazhong Agricultural University (Social Science Edition), 1, 99-105+161.

Li, Y. M. (2007). Community Governance: Micro-Foundation of Civil Society. Society, 2, 159-169+207.

Li, Y. M. (2017). New Connotation and New Actions of Chinese Social Governance. Sociological Studies, 6, 27-34.

Lu, F. Y. (1998). An Enabling Village Governance under the Background of Developed 
Private Economy. Journal of Huazhong Normal University (Humanities and Social Sciences), 2, 18-23.

Ma, H., \& Wang, J. R. (2017). Village Tyrant in Grass-Roots Political Ecology and Its Governance. Journal of Guangxi University (Philosophy and Social Sciences Edition), 6, 55-62.

O'Brien, K. J. (1994). Discussion on the Implementation of the Organic Law of the Villagers' Committee of China. Socialist Studies, 5, 61-65.

Spearman, C. E. (1999). The Abilities of Man: Their Nature and Measurement. Hangzhou: Zhejiang Education Publishing House.

Sun, X. L. (2009). Village Democracy, Roles of Village Cadres and Their Behavioral Strategies. Society, 1, 66-88+225.

Tong, Z. H. (2016). Bribery Election and the Legitimacy of Village Power in Profit-Sharing Village Governance: Discussion the History of Election in L Village. Journal of Nanjing Agricultural University (Social Science Edition), 3, 1-14+156.

Tong, Z. H., \& He, X. F. (2002). A Three-Level Analysis on the Structure of Village Power: On the Post-Election Legitimacy of Village Power. Social Science in China, 1, 158-167+208-209.

Wang, S. B. (1991). Analysis of Marginal Status and Behavior of Village Cadres. Sociological Studies, 4, 46-51.

Wu, X. Y., \& Du, X. Y. (2006). Multidimensional Perspective on the Conception of Ability. Journal of Jilin Engineering Normal University, 4, 1-5.

Wu, Y. (2002). The Dual Marginalization: A Typologic Analysis of the Part Played by and the Behavior of Village Cadres. Management World, 11, 78-85+155-156.

Xiang, H., \& Zhou, W. F. (2001). Rural Economic Elite Villager Autonomy. Society, 12, 8-11.

Xiao, T. B. (2001). Research on the Relation between the Clan and Village Governance and Village Election. Jiangxi Social Science, 9, 125-130.

Xiao, T. B. (2006). Who Is a Village Cadre? A Preliminary Analysis of the Social and Political Capital of Village Cadres. Management World, 9, 64-70.

Yang, J., Xu, X. G., \& Xu, Y. X. (2015). Towards Service-Oriented Community Governance: Integral Governance and Social Reorganization. Chinese Agriculture Journal of Polytechnic University (Social Science Edition), 3, 95-105.

Ye, B. Q. (2005). Village Elite: Intermediate Position of Village Power Structure. China Rural Survey, 1, 45-51+79.

Zhang, D. G., \& Ren, H. Y. (2008). Rural Elite Governance in Contemporary China: Limitations and Possibilities. Journal of Theory, 7, 79-82.

Zhang, J. (2011). Political Employment of Rural and Rural Cadres by Political Parties. Journal of Wuhan University of Technology (Social Science Edition), 6, 831-838.

Zhang, Y. E. (2010). An Analysis of Several Relevant Issues Concerning the Subject of Rural Governance. Rural Economy, 1, 14-19. 